\title{
Periungual capillaroscopy in psoriasis
}

\author{
Capilaroscopia periungueal em psoríase
}

\author{
Camila Ferrari Ribeiro ${ }^{1}$ \\ Ana Paula Holler ${ }^{1}$ \\ Thelma Larocca Skare ${ }^{3}$
}

\author{
Elisa Beatriz Dalledone Siqueira ${ }^{1}$ \\ Lincoln Fabrício ${ }^{2}$
}

\begin{abstract}
BACKGROUND: Nailfold capillaroscopy is a useful technique for evaluating changes in microcirculation.

OвJестіvе: To investigate changes at nailfold capillaroscopy in psoriatic patients compared with controls. METHODS: Nailfold capillaroscopy was performed in 46 psoriatic patients and 50 controls to assess microscopic morphological changes, capillary density and the presence of areas with devascularization. RESulTs: Patients with psoriasis had lower capillary density $(p=0.0005)$, increased avascular areas $(\mathrm{p}=0.0035)$ and an increased number of morphologically abnormal capillaries (coiled, $\mathrm{p}<0.0001)$ compared to controls. No association was found between capillary density and the duration of the disease $(\mathrm{p}=0.92)$ or the extent of skin involvement, as measured by the psoriasis area and severity index (PASI) score $(\mathrm{p}=0.59)$. The presence of avascular areas was more common in psoriatic individuals whose nails were affected by the condition $(\mathrm{p}=0.047)$.

CONCLUSION: Patients with psoriasis have decreased capillary density and a greater presence of morphologically abnormal capillaries when compared to controls.
\end{abstract}

Keywords: Capillaries; Microscopic angioscopy; Psoriasis; Psoriatic arthritis

\begin{abstract}
Resumo: FundAmENTOS: A capilaroscopia periungueal é um método utilizado no estudo de alterações da microcirculação.

OвJетіvo: Verificar alterações na capilaroscopia periungueal de pacientes com psoríase, comparando-os com controles saudáveis.

MÉTODos: A capilaroscopia periungueal foi realizada em 46 pacientes com psoríase e 50 controles, utilizando-se um estereomicroscópio e observando-se alterações morfológicas, densidade capilar e presença de áreas com desvascularização.

Resultados: Pacientes com psoríase tinham menor densidade capilar $(p=0,0005)$, maior presença de áreas avasculares $(\mathrm{p}=0,0035)$ e de capilares morfologicamente alterados (enrodilhados; $\mathrm{p}<0.0001)$ do que os controles. Não se encontrou associação entre densidade capilar e tempo de doença $(p=0.92)$ ou grau de envolvimento cutâneo medido pelo PASI $(\mathrm{p}=0.59)$. A presença de áreas avasculares foi mais comum em indivíduos com psoríase que tinham envolvimento ungueal $(\mathrm{p}=0,047)$.

CONCLUSÃO: Pacientes com psoríase têm menor densidade capilar e presença de capilares morfologicamente alterados em relação aos controles.

Palavras-chave: Angioscopia microscópica; Artrite psoriásica; Capilares; Psoríase
\end{abstract}

\footnotetext{
Received on 04.06.2011

Approved by the Advisory Board and accepted for publication on 10.01.2012.

* This study was conducted at the Department of Dermatology, Evangelical University Hospital of Curitiba, Evangelical College of Paraná, (HUEC-FEPAR) - Curitiba (PR), Brazil.

Conflict of interest: None

Financial funding: None

Medical Resident, Department of Dermatology, Evangelical University Hospital of Curitiba, Evangelical College of Paraná, (HUEC-FEPAR) - Curitiba (PR), Brazil.
Specialist, Preceptor of the Dermatology Residence Program, Evangelical University Hospital of Curitiba, Evangelical College of Paraná, (HUEC-FEPAR) -
Curitiba (PR), Brazil.
PhD, Full Professor of Rheumatology, Medical School, Evangelical College of Paraná, (HUEC-FEPAR) - Curitiba (PR), Brazil..

(C)2012 by Anais Brasileiros de Dermatologia
} 


\section{INTRODUCTION}

Nailfold capillaroscopy has become a diagnostic tool for collagen diseases, especially in patients with Raynaud's phenomenon and suspected scleroderma. ${ }^{1.2}$ In the case of this latter condition, nailfold capillaroscopy is useful not only for reaching diagnosis but also for providing data on the progression pattern and the severity of the disease. ${ }^{1,3}$ This diagnostic method has also been evaluated in other conditions such as psoriasis and Behçet's syndrome. ${ }^{1}$

Capillaroscopic patterns in psoriatic skin consist of tortuous, coiled and bushy capillary formations. ${ }^{4}$ In the synovial tissue of patients with psoriatic arthritis, the walls of the blood vessels are thick. However, findings in the periungual regions are controversial. Bushan et al. reported decreased vessel density and a reduction in the size of the capillary loops but found no other morphological abnormalities. ${ }^{6}$ Bartosinska et al. evaluated patients with psoriasis vulgaris and psoriatic arthritis and identified four distinct patterns: (a) normal, (b) with coiled capillary loops, (c) a pattern similar to that found in plaque psoriasis; and (d) the presence of thin and fragile capillaries in a pale background. ${ }^{7}$ The latter pattern was detected only in patients with psoriatic arthritis.

Therefore, the objective of the present study was to investigate nailfold capillaroscopy patterns in patients from the local population with and without psoriasis and psoriatic arthritis.

\section{METHODOLOGY}

This was a controlled cross-sectional study. After approval of the project by the institute's internal review board, 46 consecutive patients with psoriasis, who were attending the psoriasis outpatient clinic and who agreed to participate in the study, were recruited. Pregnant patients and those with rheumatic conditions other than psoriatic arthritis were excluded. Fifty individuals with no skin disease and no inflammatory rheumatic disease were recruited as controls. These individuals were recruited from among staff members at the psoriasis outpatient clinic (doctors and clerks) and from individuals accompanying the patients. All participants signed an informed consent form.

Patients were interviewed concerning their demographic and clinical data. They were clinically evaluated to determine the psoriasis type, the involvement of the nails and to measure the psoriasis area and severity index (PASI) score. ${ }^{8}$ Periungual capillaroscopy was performed in patients and controls using a stereomicroscope (Coleman Comp. Imp., Santo André, SP, Brazil) with 10x magnification. After immersing the area to be studied in quick-drying enamel oil, the periungual beds of the second to the fifth fingers of both hands were examined. The number of loops $/ \mathrm{mm}$ was counted and the presence of deletions and alterations in capillary morphology was observed. The absence of at least two successive capillaries was considered a focal deletion or avascular area. ${ }^{1}$ For the purpose of statistical analysis, the mean number of loops in all the nails analyzed in each patient was taken into consideration.

Data were arranged as frequency tables. The chi-square test of association was used for the nominal data and the Mann-Whitney test and the unpaired t-test were used to analyze numerical data. Correlation was evaluated using Pearson's test in the case of normal distribution and Spearman's test for non-normal distribution. Means and standard deviations were used to measure dispersion when the distribution of data was normal and medians when it was not. Statistical analysis was performed using the Graph Pad Prism software program, version 4.0. The significance level was set at 5\%.

\section{RESULTS}

Of the 46 psoriatic patients, 3 (6.5\%) had palmoplantar psoriasis and 43 (93.4\%) had psoriasis vulgaris. In this latter group, one patient had psoriasis vulgaris together with palmoplantar lesions, while another patient had palmoplantar psoriasis in association with psoriasis vulgaris lesions.

In $17 / 46$ patients $(36.9 \%)$, the nails were affected, with pitting being present in 13 patients and onychodystrophy in 5 patients, one patient having both pitting and onychodystrophy. In two of the patients with onychodystrophy, only the toes were affected. Seven of the 46 patients (15.2\%) had articular manifestations (spondylitis in two cases and oligoarticular psoriatic arthritis in the remaining cases). With respect to the psoriasis treatment, 15 patients were using methotrexate; 3 were using acitretin and 3 were on anti-tumor necrosis factor alpha (anti-TNF- $\alpha$ ) agents. Otherwise, treatment was restricted to topical medication.

The mean age of the psoriatic patients was 50.5 \pm 16.3 years (range 16 to 78 years) and the median duration of their disease was 10.0 years (range 1 to 27 years). Median PASI score was 4.45 (range 0 to 55). The mean age in the control group was $46.71 \pm 11.91$ years (range 14 to 72 years).

Mean nailfold capillary density was $7.14 \pm 0.99$ in the psoriatic patients compared to $7.76 \pm 0.68$ in the controls. In $25 / 46$ cases of psoriasis (54.3\%), coiled capillary loops were found in at least one of the periungual regions examined. In $21 / 46$ cases (45.65\%), there were areas of capillary dropout.

Table 1 compares the periungual capillaroscopy findings recorded in the psoriatic patients with those 
TABLE 1: Comparison of periungual capillaroscopy findings in psoriatic patients and controls

\begin{tabular}{llll}
\hline & Controls $\mathbf{n}=\mathbf{5 0}$ & Psoriatic Patients n=46 & p-value \\
\hline $\begin{array}{l}\text { Capillary density (mean number of } \\
\text { loops/mm } \pm \text { SD) }\end{array}$ & $7.76 \pm 0.68$ & $7.14 \pm 0.99$ & 0.0005 \\
Number of individuals with deletions & $9 / 50(18 \%)$ & $21 / 46(45.6 \%)$ & 0.0035 \\
$\begin{array}{l}\text { Presence of coiled capillaries } \\
\text { SD }=\text { standard deviation }\end{array}$ & $7 / 50(14 \%)$ & $25 / 46(54.3 \%)$ & $<0.0001$ \\
\hline
\end{tabular}

in the control group.

No correlation was found between the mean capillary density per millimeter and the PASI score $(\mathrm{p}$ $=0.588, \mathrm{r}=0.082 ; 95 \% \mathrm{CI}=-0.22$ to 0.37 ; Spearman's test) or between the mean capillary density per millimeter and the duration of the disease $(\mathrm{p}=0.92 ; \mathrm{r}=$ $0.014 ; 95 \% \mathrm{CI}=-0.32$ to 0.28 ; Pearson's test).

Table 2 compares data from the psoriatic patients whose nails were affected by the disease with data from the psoriatic patients whose nails were not affected and with the controls. In table 3, the capillaroscopy data are compared between patients with and without psoriatic arthritis.

\section{DISCUSSION}

The microcirculation in the skin of psoriatic patients is significantly different from that of individuals without the disease. The dermal and epidermal papillae become edematous, with dilated and coiled capillary loops. ${ }^{9}$ A greater number of endothelial pores has been described in the postcapillary venule, resulting in increased excretion of albumin and other blood proteins. ${ }^{4}$ Blood flow appears to be increased at the affected sites. ${ }^{4,10,11}$

Vascular changes appear to precede the onset of skin lesions and, interestingly, have also been described by some authors in the healthy skin of patients with psoriasis. ${ }^{12,13}$ Levels of angiogenic factors such as transforming growth factor beta (TGF- $\beta$ ), plateletderived growth factor (PDGF) and vascular endothelial growth factor (VEGF) have been found to be high. ${ }^{14,15}$ The clinical resolution of skin lesions is associated with the return of these microvasculature changes to normal. ${ }^{9}$
Nailfold capillaroscopy is an efficient and noninvasive technique for the evaluation of local microcirculation. Findings in psoriasis are conflicting, apparently reflecting the polymorphous nature of this disease, which not only may present in several different forms, but also may or may not involve nail disease and various forms of arthritis. Zaric et al. reported a decrease in the size of the nailfold capillary loops in patients with the skin disease and arthritis. ${ }^{16}$ Salli et al. evaluated 18 patients with psoriatic arthritis and reported morphological changes such as coiled and folded capillaries as well as decreased density, the latter being a typical finding in mutilating psoriatic arthritis. ${ }^{17}$ Brushan et al. evaluated 43 patients, 13 with nail involvement and 6 with arthritis of the distal interphalangeal joints. Those authors reported decreased density of loops in the patients with nail involvement and a decrease in the size of the capillaries in those with arthritis of the distal interphalangeal joints. ${ }^{6}$ No morphological abnormalities were reported.

In the present study sample, there were quantitative changes, with reduced capillary density and the presence of dropout, as well as morphological alterations and the presence of coiled vessels. None of these findings was associated with the duration of the disease or with its severity, as measured by the PASI score, or with the presence of arthritis. However, it is important to remember that in this sample there were few cases of arthritis and there was no involvement of the distal interphalangeal joints in any of the patients. Avascular areas were more common in those in whom the nails were affected, which may suggest the existence of trophic disturbances in the periungual region of these patients.

TABLE 2: Periungual capillaroscopy findings in psoriatic patients with and without nail involvement

\begin{tabular}{llll}
\hline & $\begin{array}{l}\text { Psoriasis with nail } \\
\text { involvement }\end{array}$ & $\begin{array}{l}\text { Psoriasis without } \\
\text { nail involvement }\end{array}$ & P-value \\
\hline $\begin{array}{l}\text { Capillary density (mean number of } \\
\text { loops/mm } \pm \text { SD) }\end{array}$ & $6.97 \pm 0.85$ & $7.25 \pm 1.07$ & 0.36 \\
$\begin{array}{l}\text { Number of individuals with deletions } \\
\text { Presence of coiled capillaries }\end{array}$ & $\begin{array}{l}11 / 17(64.7 \%) \\
12 / 17(70.5 \%)\end{array}$ & $10 / 29(34.4 \%)$ & 0.047 \\
SD $=$ standard deviation & $14 / 29(48.2 \%)$ & 0.14 \\
\hline
\end{tabular}


TABLE 3: Periungual capillaroscopy findings in psoriatic patients with and without joint involvement

\begin{tabular}{llll}
\hline & $\begin{array}{l}\text { Psoriasis with } \\
\text { joint involvement }\end{array}$ & $\begin{array}{l}\text { Psoriasis without } \\
\text { joint involvement }\end{array}$ & P-value \\
\hline $\begin{array}{l}\text { Capillary density (mean number of } \\
\text { loops/mm } \pm \text { SD) }\end{array}$ & $7.41 \pm 0.77$ & $7.08 \pm 1.03$ & 0.40 \\
$\begin{array}{l}\text { Number of individuals with deletions } \\
\text { Presence of coiled capillaries }\end{array}$ & $5 / 8(62.5 \%)$ & $16 / 38(42.1 \%)$ & 0.43 \\
SD= standard deviation & $5 / 8(62.5 \%)$ & $21 / 38(55.2 \%)$ & 1.0 \\
\hline
\end{tabular}

\section{CONCLUSION}

In conclusion, in this sample of patients with psoriasis, abnormalities were found at periungual capillaroscopy, with reduced density and the presence of coiled and tortuous capillaries. Avascular areas were more common in patients whose nails were affected by the disease.

\section{REFERENCES}

1. Gallucci F, Russo R, Buono R, Acampora R, Madrid E, Uomo G. Indications and results of videocapillaroscopy in clinical practice. Adv Med Sci. 2008;53:149-57.

2. Kayser C, Andrade LEC. Capilaroscopia periungueal: importância para a investigação do fenômeno de Raynaud e doenças do espectro da esclerose sistêmica. Rev Bras Reum. 2004;44:16-52.

3. Grassi W, De Angelis R. Capillaroscopy: questions and answers. Clin Rheumatol. 2007;26:2009-16.

4. Hern S, Mortimer OS. In vivo quantification of microvessels in clinically univolved psoriatic skin and in normal skin. Br J Dermatol. 2007;156:1224-9.

5. Espinoza LR, Vasey FB, Espinoza GG, Bocanegra TS, Germain BF. Vascular changes in psoriatic synovium. A light and electron microscopy study. Arthritis Rheum. 1982;25:677-84.

6. Bhusman M, Moore T, Herrick A, Griffiths CEM. Naildfold video capillaroscopy in psoriasis. Br J Dermatol. 2000;142:1171-6.

7. Bartosinska J, Chodorowska G. Original proposal of capillaroscopic images classification in psoriasis vulgaris and psoriatic arthritis. Adv Dermatol Allergo. 2009;26:1724.

8. Langley RG, Ellis CN. Evaluating psoriasis with psoriasis area and severity index, psoriasis global assessment, and lattice system physician's global assessment. J Am Acad Dermatol. 2004;51:563-9.

9. Stinco G, Lautieri S, Valent F, Patrone P. Cutaneous vascular alterations in psoriatic patients treated with cyclosporine. Acta Derm Venereol. 2007;87:152-4.

10. Ferguson EH, Epstein WL. Clearence of I 131 injected intralesionally in patients with psoriasis. J Invest Dermatol. 1961:37:441-5.

11. Hern S, Stantos AW, Mellor R, Levick JR, Mortimer PS. Control of cutaneous blood vessels in psoriatic plaques. J Invest Dermatol. 1999;113:127-32.

12. Goodfield M, Hull SM, Holland D, Roberts G, Wood E, Reid S, et al. Investigations of the active edge of plaque psoriasis: vascular proliferations precedes change in epidermal Keratin. Br J Dermatol. 1994;131:808-13.
13. Gordon M, Johnson WC. Histopathology and histochemistry of psoriasis. I. The active lesion and clinically normal skin. Arch Dermatol. 1967;95:402-7.

14. Veale DJ, Ritchlin C, Fitzgerald 0 . Immunopathology of psoriasis and psoriatic arthritis. Ann Rheum Dis. 2005;64 Suppl 2:ii26-9.

15. Bressan AL, Gripp A, Oliveira EF, Silva RS. Síndrome de extravasamento capilar sistêmico. An Bras Dermatol. 2011;86:593-5.

16. Zaric D, Clemmerson 0, Worm A, Stahl D. Capillary microscopy of the nail fold in patients with psoriasis and psoriatic arthritis. Dermatologica. 1982;164:10-4.

17. Salli L, Raimondi F, Pappalardo A. [Periungueal capillaroscopy in psoriatic arthritis]. Clin Ter. 1999;150:409-12.

\author{
MAILING ADDRESS: \\ Thelma Larocca Skare \\ Rua Sete de Setembro, 4713 \\ 80240-000 Curitiba, PR, Brazil \\ E-mail:tskare@onda.com.br
}

How to cite this article: Ribeiro CF, Siqueira EBD, Holler AP, Fabrício L, Skare TL. Periungual capillaroscopy in psoriasis. An Bras Dermatol. 2012;87(4):550-3. 